\title{
Perception of Filipino Students towards Brand Equity in social media
} KIM EDWARD S. SANTOS, мва

\author{
Instructor, Atate Campus, Nueva Ecija University of Science and Technology, Philippines \\ kimnyte@gmail.com
}

\begin{abstract}
Branding is crucial because it not only creates an emotional connection with customers, but also informs them about your business. The study described Filipino students enrolled in a Bachelor of Science in Business Administration program's perceptions of brand associations, brand loyalty, brand awareness, and brand image via social media. The study used a quantitative descriptive method. The study surveyed 87 students (45 males and 42 females) enrolled in a Bachelor of Science in Business Administration program at private colleges and institutions in Nueva Ecija using convenience sampling. The present study examined the perception of Filipino students towards brand equity in social media. The researcher concluded that students focused brand awareness, brand loyalty, brand image and brand association, respectively. Further, they are fully aware of the brand and are familiar with the products they purchase. Students, as consumers, are satisfied with the product they usually purchase even it appeared on social media. The researcher recommends to companies regarding their brand equity that rather than receiving a broad and simplified definition of brand equity in social media, they may be able to pinpoint exactly where the brand is falling short in terms of product awareness and desirability. Companies must also allow focusing on developing and concentrating marketing operations in specific channels. They have to heighten the necessity for their businesses to be active and engaged on social media in order to demonstrate their values, products and services, and inventiveness. Lastly, further research should be conducted to respondents across different characteristics of the consumers.
\end{abstract}

Keywords - Brand, Brand Awareness, Brand Equity, Brand Image, Brand Association, Brand Loyalty.

\section{INTRODUCTION}

Branding is crucial because it not only creates an emotional connection with customers, but also informs them about your business. It's a way of differentiating oneself from the competition and demonstrating why you're the preferred choice. Branding has risen to prominence as a top management priority over the last decade, owing to the rising recognition that brands are one of a firm's most important intangible assets (Keller \& Lehmann, 2006).

In brand association, consumers are invited to generate brand mapping and then asked to form networks of these associations as connections to the brand and to one another (John et al., 2006). As customers gain familiarity with a brand beyond mere awareness through a variety of direct and indirect encounters, their associations with the brand can grow deeper and perhaps more favorable, assuming the experiences were pleasant (Dew \& Kwon, 2010).

Brand awareness is a term that relates to a consumer's ability to recall or recognize a brand, or simply to their knowledge of a brand (Huang, R., \& Sarigöllü, 2014). When a consumer has a high level of awareness and familiarity with a brand and a strong favorable, distinctive brand association in their memory, this is considered brand equity (Atilgan et al., 2005).

Brand loyalty is described as a client's degree of attachment to a particular brand, as demonstrated by their repeated purchases regardless of the marketing pressure exerted by competitor companies (Malik et al., 2013). Given the importance of brand loyalty in building brand equity, businesses should put more effort into developing customer loyalty for their products (Emari et al., 2012).

Brand image is the primary driver of brand equity, a concept that refers to a consumer's overall perception and feeling toward a brand and how that perception and emotion affects consumer behavior (Zhang, 2015). To develop a brand image, businesses must increase advertising awareness and brand association through marketing activities that contribute to a particular brand becoming the customer's preferred product (Alhaddad, 2015).

With an understanding of the components of brand equity, the researcher sought to ascertain Filipino students' attitudes on branding via social media.

\section{OBJECTIVES OF THE STUDY}

The study examined Filipino students enrolled in a Bachelor of Science in Business Administration 
program's perceptions of brand associations, brand loyalty, brand awareness, and brand image via social media.

\section{METHODOLOGY}

The study used a quantitative descriptive method since it is a fundamental research methodology that examines the situation in its current state (Williams, 2007). The study surveyed 87 students (45 male and 42 female) enrolled in a Bachelor of Science in Business Administration program at private colleges in Nueva Ecija using convenience sampling. The study used survey research because it entails research techniques such as data analysis and interpretation (Salaria, 2012). The questionnaire was adopted from Sasmita \& Suki (2015).

\section{RESULTS AND DISCUSSIONS}

Table 1. Brand Association

\begin{tabular}{|c|c|c|}
\hline Statement & Mean & $\begin{array}{c}\text { Verbal } \\
\text { Interpretation }\end{array}$ \\
\hline $\begin{array}{l}\text { 1. I trust the company who owns the particular product/brand that appeared in the social } \\
\text { media. }\end{array}$ & 3.17 & Agree \\
\hline 2. This particular product/brand that appeared in the social media is familiar to me. & 3.21 & Agree \\
\hline $\begin{array}{l}\text { 3. There are reasons to buy this particular product/brand over the competing } \\
\text { product/brand that appeared in the social media. }\end{array}$ & 3.54 & Strongly Agree \\
\hline 4. This particular product/brand that appeared in the social media has its own personality. & 2.92 & Agree \\
\hline $\begin{array}{l}\text { 5. This particular product/brand is different in comparison with other competing } \\
\text { particular product/brand that appeared in social media. }\end{array}$ & 2.91 & Agree \\
\hline Average Weighted Mean & 3.15 & Agree \\
\hline
\end{tabular}

\section{Legend Verbal Interpretation (VI)}

3.25 - 4.00 Strongly Agree (SA)

2.50 - 3.24 Agree (A)

1.75 - 2.49 Disagree (D)

1.00 - 1.74 Strongly Disagree (SD)

Table 1 presents the perceptions of students on brand association. Student - respondents got an average of weighted mean of 3.15, which has a verbal interpretation of "Agree". They strongly agreed on Statement 3 "There are reasons to buy this particular product/brand over the competing product/brand that appeared in the social media." (Mean $=3.54)$. This result means that student respondents pay attention on the details and uniqueness of certain brands. This affirms Keller (2003), brand connections may be traced back to perceived benefits and product experiences, as well as consumer sentiments, thoughts, and attitudes toward a brand.

Table 2. Brand Loyalty

\begin{tabular}{|c|c|c|}
\hline Statement & Mean & $\begin{array}{c}\text { Verbal } \\
\text { Interpretation }\end{array}$ \\
\hline 1. I am satisfied with product/brand that appeared in the social media. & 3.52 & Strongly Agree \\
\hline 2. I would recommend this particular product/brand to others through social media. & 3.21 & Agree \\
\hline 3. I will not switch to another product/brand that appeared in the social media next time. & 2.92 & Agree \\
\hline $\begin{array}{l}\text { 4. I will use this particular product/brand as my first choice in comparison with the other } \\
\text { product/brand. }\end{array}$ & 3.05 & Agree \\
\hline 5. I regularly refer this particular product/brand through the social media. & 3.24 & Agree \\
\hline Average Weighted Mean & 3.19 & Agree \\
\hline
\end{tabular}

Legend Verbal Interpretation (VI)

3.25 - 4.00 Strongly Agree (SA)

2.50 - 3.24 Agree (A)

1.75 - 2.49 Disagree (D)

1.00 - 1.74 Strongly Disagree (SD) 
Table 2 presents the perceptions of students on brand loyalty. Student - respondents got an average of weighted mean of 3.19, which has a verbal interpretation of "Agree". They strongly agreed on Statement 1 "I am satisfied with product/brand that appeared in the social media." (Mean = 3.52). The result shows how the student respondents get information of the product/brand using social media. Social media is an easy access to know the product quality and value, and to have faster communication with the company. Customer/brand loyalty in cyberspace, according to Schultz (2000), is evolving from a product-driven, marketer-controlled notion to a distribution-driven, consumer-controlled, and technology-facilitated idea.

Table 3. Brand Awareness

\begin{tabular}{|c|c|c|c|}
\hline \multicolumn{2}{|r|}{ Statement } & \multirow{2}{*}{$\frac{\text { Mean }}{3.54}$} & \multirow{2}{*}{$\begin{array}{c}\begin{array}{c}\text { Verbal } \\
\text { Interpretation }\end{array} \\
\text { Strongly Agree }\end{array}$} \\
\hline & $\begin{array}{l}\text { I can quickly recall symbol or logo of the particular product/brand that appeared in the } \\
\text { social media. }\end{array}$ & & \\
\hline 2 . & $\begin{array}{l}\text { Some characteristics of the particular product/brand that appeared in the social media } \\
\text { come to my mind quickly. }\end{array}$ & 3.43 & Strongly Agree \\
\hline 3 . & I am aware about this the particular product/brand that appeared in the social media. & 3.09 & Agree \\
\hline & $\begin{array}{l}\text { I can recognize this particular product/brand in comparison with other competing } \\
\text { product/brand that appeared in the social media. }\end{array}$ & 3.24 & Agree \\
\hline \multirow[t]{2}{*}{5 . } & I know how this particular product/brand looks like & 3.32 & Strongly Agree \\
\hline & Average Weighted Mean & 3.32 & Strongly Agree \\
\hline
\end{tabular}

\section{Legend Verbal Interpretation (VI) \\ 3.25 - 4.00 Strongly Agree (SA) \\ 2.50 - 3.24 Agree (A) \\ 1.75 - 2.49 Disagree (D) \\ 1.00 - 1.74 Strongly Disagree (SD)}

Table 3 presents the perceptions of students on brand loyalty. Student - respondents got an average of weighted mean of 3.32, which has a verbal interpretation of "Strongly Agree". They strongly agreed on Statement 1 "I can quickly recall symbol or logo of the particular product/brand that appeared in the social media." (Mean $=3.54$ ), Statement 2 "Some characteristics of the particular product/brand that appeared in the social media come to my mind quickly." (Mean = 3.43), and Statement 5 "I know how this particular product/brand looks like"
(Mean = 3.32). The data suggests that studentrespondents are fully aware of the brand and are familiar with the products they purchase. They are familiar with them and can easily recognize. Gustafson and Chabot (2007) confirms that due to understanding of the brand and its distinctiveness, brand awareness plays a vital part in the purchase of a product or service, and may have an influence over customers' perceived risk appraisal and their level of assurance about the buying decision.

\section{Table 4. Brand Image}

\begin{tabular}{|c|c|c|}
\hline Statement & Mean & $\begin{array}{c}\text { Verbal } \\
\text { Interpretation }\end{array}$ \\
\hline 1. This particular product/brand is well established. & 3.51 & Strongly Agree \\
\hline 2. This particular product/brand has a clean image. & 3.03 & Agree \\
\hline $\begin{array}{l}\text { 3. This particular product/brand has a differentiated image in comparison with the other } \\
\text { product/brand. }\end{array}$ & 2.92 & Agree \\
\hline $\begin{array}{l}\text { 4. It makes sense to buy this purchased brand instead of any other brand, even if they } \\
\text { are the same. }\end{array}$ & 3.50 & Strongly Agree \\
\hline $\begin{array}{l}\text { 5. Even if another brand has the same features as this purchased brand, I would prefer to } \\
\text { buy this brand. }\end{array}$ & 2.96 & Agree \\
\hline Average Weighted Mean & 3.18 & Agree \\
\hline
\end{tabular}

Legend Verbal Interpretation (VI)

3.25 - 4.00 Strongly Agree (SA) 
$2.50-3.24$ Agree (A)

$1.75-2.49$ Disagree (D)

$1.00-1.74$ Strongly Disagree (SD)

Table 4 presents the perceptions of students on brand image. Student - respondents got an average of weighted mean of 3.18, which has a verbal interpretation of "Agree". They strongly agreed on Statement 1 "This particular product/brand is well established." (Mean = 3.51) and Statement 4 "It makes sense to buy this purchased brand instead of any other brand, even if they are the same." (Mean $=3.50$ ). This result shows how student respondents display general good attitude toward the brand, and the brand will have a positive brand image. According to Hsieh and Lindridge (2005) a brand's image is a set of perceptions about a company based on people's memories of brand associations.

\section{Table 5. Summary of Ratings}

\begin{tabular}{clcc}
\hline & Variables & $\begin{array}{c}\text { Weighted } \\
\text { Mean }\end{array}$ & Rank \\
\hline 1. & Brand Association & 3.15 & 4 \\
2. & Brand Loyalty & 3.19 & 2 \\
3. & Brand Awareness & 3.32 & 1 \\
4. & Brand Image & 3.18 & 3 \\
\hline
\end{tabular}

Table 5 shows the summary ratings of the perception of Filipino students towards brand equity in social media. Based on the result, brand awareness (Mean = 3.32) ranked first among the variables in brand equity and, while, brand association (Mean $=3.15$ ) ranked last. Other variables were brand loyalty $($ Mean $=3.19)$ and brand image (Mean $=3.18$ ). The data implies that studentrespondents focused the most on familiarizing and recognizing the product brand and focused the least on associating of a brand with a specific concept that they remember when they see that brand.

\section{CONCLUSIONS AND RECOMMENDATIONS}

The present study examined the perception of Filipino students towards brand equity in social media. The researcher concluded that students focused brand awareness, brand loyalty, brand image and brand association, respectively. Further, they are fully aware of the brand and are familiar with the products they purchase. Students, as consumers, are satisfied with the product they usually purchase even it appeared on social media.

The researcher recommends to companies regarding their brand equity that rather than receiving a broad and simplified definition of brand equity in social media, they may be able to pinpoint exactly where the brand is falling short in terms of product awareness and desirability.
Companies must also allow focusing on developing and concentrating marketing operations in specific channels. They have to heighten the necessity for their businesses to be active and engaged on social media in order to demonstrate their values, products and services, and inventiveness. Lastly, further research should be conducted to respondents across different characteristics of the consumers.

\section{REFERENCES}

[1] Alhaddad, A. (2015). Perceived quality, brand image and brand trust as determinants of brand loyalty. Journal of Research in Business and Management, 3(4), 01-08.

[2] Atilgan, E., Aksoy, Ş., \& Akinci, S. (2005). Determinants of the brand equity: A verification approach in the beverage industry in Turkey. Marketing intelligence \& planning.

[3] Dew, L., \& Kwon, W. S. (2010). Exploration of apparel brand knowledge: Brand awareness, brand association, and brand category structure. Clothing and Textiles Research Journal, 28(1), 3-18.

[4] Emari, H., Jafari, A., \& Mogaddam, M. (2012). The mediatory impact of brand loyalty and brand image on brand equity. African Journal of Business Management, 6(17), 5692-5701.

[5] Gustafson, T., \& Chabot, B. (2007). Brand Awareness. Cornell Maple Bulletin , 105.

[6] Hsieh, M.H. and Lindridge, A. (2005), "Universal appeals with local specifications", The Journal of Product and Brand Management, Vol. 14 No. 1, pp. 14-28.

[7] Huang, R., \& Sarigöllü, E. (2014). How brand awareness relates to market outcome, brand equity, and the marketing mix. In Fashion branding and consumer behaviors (pp. 113-132). Springer, New York, NY.

[8] John, D. R., Loken, B., Kim, K., \& Monga, A. B. (2006). Brand concept maps: A methodology for identifying brand association networks. Journal of marketing research, 43(4), 549-563.

[9] Keller, K. L. (2003), "Brand synthesis: the multidimensionality of brand knowledge", The Journal of Consumer Research, Vol. 29, March, pp. 595-600.

[10] Keller, K. L., \& Lehmann, D. R. (2006). Brands and branding: Research findings and future priorities. Marketing science, 25(6), 740-759. 
[11] Keller, K. L. (2009). Building strong brands in a modern marketing communications environment. Journal of marketing communications, 15(2-3), 139-155.

[12] Malik, M. E., Ghafoor, M. M., Hafiz, K. I., Riaz, U., Hassan, N. U., Mustafa, M., \& Shahbaz, S. (2013). Importance of brand awareness and brand loyalty in assessing purchase intentions of consumer. International Journal of business and social science, 4(5).

[13] Salaria, N. (2012). Meaning of the term descriptive survey research method. International journal of transformations in business management, 1(6), 1-7.

[14] Sasmita, J., \& Suki, N. M. (2015). Young consumers' insights on brand equity: Effects of brand association, brand loyalty, brand awareness, and brand image. International journal of retail \& distribution management.

[15] Schultz, D. (2000) "Customer/Brand Loyalty in an Interactive Marketplace," Journal of Advertising Research, 40 (3): 41-53

[16] Williams, C. (2007). Research methods. Journal of Business \& Economics Research (JBER), 5(3). https://doi.org/10.19030/jber.v5i3.2532

[17]Zhang, Y. (2015). The impact of brand image on consumer behavior: A literature review. Open journal of business and management, 3(01), 58. 